\title{
Organic anion transporting polypeptides expressed in liver and brain mediate uptake of microcystin
}

\author{
W.J. Fischer ${ }^{\mathrm{a}, 1}$, S. Altheimer ${ }^{\mathrm{a}}$, V. Cattori ${ }^{\mathrm{b}}$, P.J. Meier ${ }^{\mathrm{b}}$, D.R. Dietrich ${ }^{\mathrm{a}, *}$, B. Hagenbuch ${ }^{\mathrm{b}}$ \\ ${ }^{a}$ Environmental Toxicology, University of Konstanz, Konstanz, Germany \\ ${ }^{\mathrm{b}}$ Division of Clinical Pharmacology and Toxicology, Department of Medicine, University Hospital, Zurich, Switzerland
}

\begin{abstract}
Microcystins are toxins produced by freshwater cyanobacteria. They are cyclic heptapeptides that exhibit hepato- and neurotoxicity. However, the transport systems that mediate uptake of microcystins into hepatocytes and across the blood-brain barrier have not yet been identified. Using the Xenopus laevis oocyte expression system we tested whether members of the organic anion transporting polypeptide superfamily (rodent: Oatps; human: OATPs) are involved in transport of the most common microcystin variant microcystin-LR by measuring uptake of a radiolabeled derivative dihydromicrocystin-LR. Among the tested Oatps/OATPs, rat Oatp1b2, human OATP1B1, human OATP1B3, and human OATP1A2 transported microcystin-LR 2- to 5-fold above water-injected control oocytes. This microcystin-LR transport was inhibited by co-incubation with the known Oatp/OATP substrates taurocholate (TC) and bromosulfophthalein (BSP). Microcystin-LR transport mediated by the human OATPs was further characterized and showed saturability with increasing microcystin-LR concentrations. The apparent $K_{\mathrm{m}}$ values amounted to $7 \pm 3 \mu \mathrm{M}$ for OATP1B1, $9 \pm 3 \mu \mathrm{M}$ for OATP1B3, and $20 \pm 8 \mu \mathrm{M}$ for OATP1A2. No microcystin-LR transport was observed in oocytes expressing Oatp1a1, Oatp1a4, and OATP2B1. These results may explain some of the observed organ-specific toxicity of microcystin-LR. Oatp1b2, OATP1B1, and OATP1B3 are responsible for microcystin transport into hepatocytes, whereas OATP1A2 mediates microcystin-LR transport across the blood-brain barrier.
\end{abstract}

Keywords: Environmental toxins; Natural toxins; Microcystin; Cyanobacteria; Blood-brain barrier; Hepatocyte; Organic anion transport; Oatp; OATP

\section{Introduction}

Microcystins are naturally occurring toxins produced by freshwater cyanobacteria and can be found in lakes, ponds, and rivers that are often used for recreational activities (Chorus et al., 2000; Watanabe et al., 1996). Thus, besides menacing terrestrial and aquatic wildlife and livestock (Carmichael, 1994; Fischer and Dietrich, 2000; Schwimmer and Schwimmer, 1968), cyanobacteria also represent a threat

Abbreviations: OATP, human organic anion transporting polypeptide; Oatp, rodent organic anion transporting polypeptide; BSP, bromosulfophthalein; TC, taurocholate.

* Corresponding author. Environmental Toxicology, University of Konstanz, Jacob-Burckhardt Street 25, PO Box X-918, D-78457 Konstanz, Germany. Fax: +49 7531883170 .

E-mail address: Daniel.Dietrich@uni-konstanz.de (D.R. Dietrich).

1 Present address: Ciba Specialty Chemicals, Basel, Switzerland. to human health (Jochimsen et al., 1998; Teixeira et al., 1993). In 1996, a hemodialysis unit in Caruaru, Brazil, used water for dialysis from a reservoir, which was contaminated with blue-green algae and contained microcystins. Sixty of the 126 intoxicated patients died of severe microcystininduced neurotoxicity or toxic liver failure (Jochimsen et al., 1998; Pouria et al., 1998). Microcystins act by inhibiting Ser/ Thr protein phosphatase-1 and -2A (Mackintosh et al., 1990), which leads to disruption of the cytoskeleton and subsequent cell death (Eriksson et al., 1989).

Target organs of microcystin are mainly the liver and the brain. This requires uptake of microcystin across the sinusoidal (basolateral) plasma membrane of hepatocytes and its transport across the blood-brain barrier. In rat hepatocytes, basolateral uptake of microcystin was inhibited by cholate, taurocholate (TC), and bromosulfophthalein (BSP) (Eriksson et al., 1990; Runnegar et al., 1995). All 
latter compounds are substrates of the organic anion transporting polypeptide (rodent: Oatps; human: OATPs) superfamily of membrane transporters (Hagenbuch and Meier, 2003, 2004) that are classified within the SLCO family of solute carriers (Human Gene Nomenclature Committee Database) (Hagenbuch and Meier, 2004). Oatps/OATPs mediate $\mathrm{Na}^{+}$-independent uptake of a wide variety of amphipathic organic compounds including bile salts, organic anionic dyes, steroids and steroid conjugates, drugs, various peptides, and toxins (Hagenbuch and Meier, 2003). Oatps/OATPs that are expressed in the brain (bloodbrain barrier, choroid plexus) as well as in the liver include rat Oatp1a1 (Jacquemin et al., 1994), rat Oatpla4 (Abe et al., 1998; Noé et al., 1997), human OATP1A2 (Kullak-Ublick et al., 1995), and human OATP2B1 (Kullak-Ublick et al., 2001). Rat Oatp1b2 (Cattori et al., 2000), human OATP1B1 (Abe et al., 1999; Hsiang et al., 1999; König et al., 2000b), and human OATP1B3 (König et al., 2000a) are primarily expressed in the liver. In the present study, we used the radiolabeled dihydromicrocystin-LR epimer $\left[\mathrm{L}-\mathrm{MeAla}^{7}\right] \mathrm{mi}-$ crocystin-LR (Meriluoto et al., 1990), which was previously shown to have similar characteristics as native microcystins (Meriluoto et al., 1990). The study served to investigate whether the hepato- and neurotoxicity observed after microcystin intoxication (Jochimsen et al., 1998; Pouria et al., 1998) could be explained by microcystin transport mediated by members of the Oatp/OATP superfamily that are expressed in hepatocytes and in the blood-brain barrier.

\section{Materials and methods}

Animals. Female Xenopus laevis were purchased from the African Xenopus facility c.c, Noordhoek, Rep. South Africa.

Chemicals. [ $\left.{ }^{3} \mathrm{H}\right]$-dihydromicrocystin-LR $(0.5 \mathrm{mCi} / \mathrm{mmol})$ was prepared as described (Meriluoto et al., 1990). $\left[{ }^{3} \mathrm{H}\right]$ Estrone-3-sulfate $(53 \mathrm{Ci} / \mathrm{mmol})$ was obtained from NEN Life Science Products (Boston, MA), $\left[\gamma_{-}{ }^{32} \mathrm{P}\right] \mathrm{ATP}$ $(3000 \mathrm{Ci} / \mathrm{mmol})$ was purchased from Amersham (Buckinghamshire, UK).

Uptake studies in X. laevis oocytes. Complementary RNA was transcribed in vitro from linearized cDNA using the mMESSAGE mMACHINE T7 kit (Ambion, Austin, TX). $X$. laevis oocytes were prepared as described (Hagenbuch et al., 1996) and injected either with $50 \mathrm{nl}$ of water or with $5 \mathrm{ng}$ of cRNA in $50 \mathrm{nl}$ of water. After 3 days in culture at $18{ }^{\circ} \mathrm{C}$ with a daily change of Barth's solution, uptake of radiolabeled substrate was measured at $25{ }^{\circ} \mathrm{C}$ in $100 \mu \mathrm{l}$ of uptake solution containing $100 \mathrm{mM} \mathrm{NaCl}, 2 \mathrm{mM}$ $\mathrm{KCl}, 1 \mathrm{mM} \mathrm{MgCl}, 1 \mathrm{mM} \mathrm{CaCl} 2$, and $10 \mathrm{mM}$ HEPES adjusted to $\mathrm{pH} 7.5$ with Tris as described (Reichel et al., 1999).
Protein phosphatase-1 and $-2 A$ inhibition assay. Preparation of $\left[\gamma_{-}{ }^{32} \mathrm{P}\right]$ phosphorylase-a and the protein phosphatase- 1 and $-2 \mathrm{~A}$ inhibition assay was carried out as described (Cohen et al., 1988; MacKintosh, 1993). Assays were performed in $60-\mu 1$ reactions consisting of $20 \mu 1 \mathrm{X}$. laevis oocyte-extract, $20 \mu \mathrm{l}$ assay buffer, and $20 \mu \mathrm{l}\left[\gamma^{\left.-{ }^{32} \mathrm{P}\right] \mathrm{phos}-}\right.$ 32P]phosphorylase-a substrate for $10 \mathrm{~min}$ at $30{ }^{\circ} \mathrm{C}$. The reaction was stopped by addition of $180 \mu \mathrm{l}$ of $20 \%$ (w/v) trichloro-acetic acid, kept on ice for $10 \mathrm{~min}$, and centrifuged at $17500 \times g$ for $5 \mathrm{~min}$. For acid molybdate extraction of inorganic $\left[{ }^{32} \mathrm{P}\right]$ phosphate, $200 \mu \mathrm{l}$ of the supernatant was mixed with $200 \mu 11.25 \mathrm{mM} \mathrm{KH}_{2} \mathrm{PO}_{4}$ in $0.5 \mathrm{M} \mathrm{H}_{2} \mathrm{SO}_{4}, 500 \mu \mathrm{l}$ isobutanol/heptane (1:2), and 100 $\mu \mathrm{l}$ ammonium molybdate $(5 \% \mathrm{w} / \mathrm{v})$. After separation of the organic and aqueous phase, $300 \mu \mathrm{l}$ of the organic phase was added to $3 \mathrm{ml}$ of scintillation fluid (Ready Safe, Beckman, USA) and subjected to $\beta$-scintillation spectrometry.

Statistical analysis. Data are expressed as mean \pm SE. To compare uptake into water injected with cRNA-injected oocytes, the unpaired Student's $t$ test was used. For comparison of protein phosphatase-1 and -2A inhibition, data (mean $\pm \mathrm{SD}$ ) were subjected to ANOVA followed by a Tukey's test, significance levels were determined at $P<0.05$.

\section{Results}

Transport of microcystin by liver Oatps/OATPs

Several Oatps/OATPs are expressed in hepatocytes where they mediate uptake of numerous organic compounds from blood plasma. To determine whether one of these transporters could mediate uptake of microcystinLR into hepatocytes, we expressed these transporters in the $X$. laevis oocyte expression system and measured uptake of radiolabeled microcystin-LR. As demonstrated in Fig. 1, rat Oatp1b2-expressing oocytes accumulated microcystin-LR about 2-fold. Furthermore, human OATP1B1 and OATP1B3 showed an approximately 3to 4-fold higher uptake of microcystin-LR as compared to water-injected control oocytes. No significant microcystinLR uptake was observed for rat Oatp1a1-, rat Oatp1a4-, and human OATP2B1-expressing oocytes although they were able to mediate uptake of the positive control estrone-3-sulfate (data not shown). To further characterize microcystin-LR transport mediated by the human OATPs, we performed inhibition experiments and saturation kinetics. Co-incubation of OATP1B1- and OATP1B3expressing oocytes with microcystin-LR and two known OATP substrates, either $100 \mu \mathrm{M}$ TC (Fig. 2, hatched bars) or $50 \mu \mathrm{M}$ BSP (Fig. 2, open bars), reduced microcystin-LR uptake into the oocytes almost completely. Initial experiments demonstrated that microcystin- 


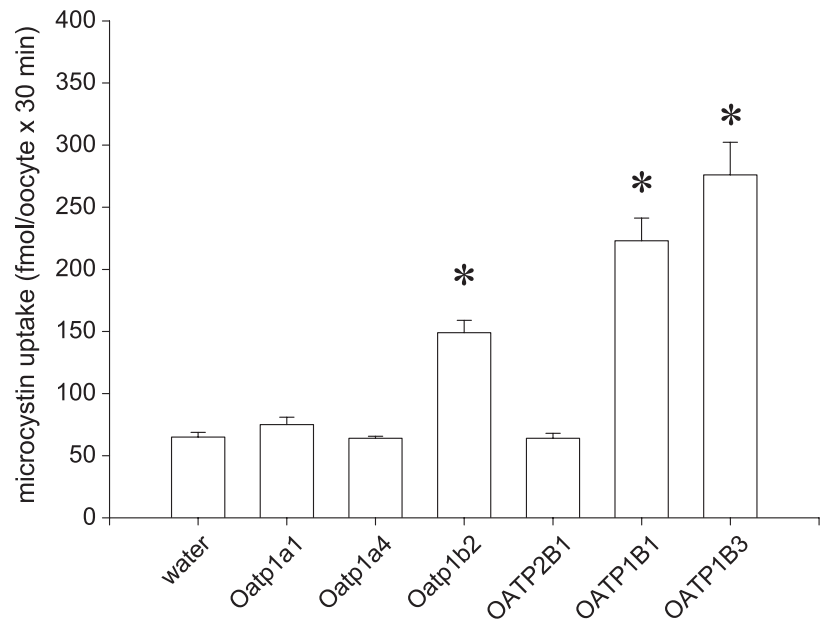

Fig. 1. Transport of microcystin-LR by liver Oatps/OATPs expressed in $X$. laevis oocytes. Oocytes were injected with $5 \mathrm{ng}$ of the respective cRNAs or with $50 \mathrm{nl}$ of water. After 3 days in culture, uptake of $4 \mu \mathrm{M}$ microcystin-LR was measured over $30 \mathrm{~min}$ at $25{ }^{\circ} \mathrm{C}$. Bars represent means $\pm \mathrm{SE}$ of $8-10$ determinations. $*$ Denotes significantly different from water-injected oocytes $(P<0.05)$.

LR uptake was linear over at least $20 \mathrm{~min}$ (data not shown). Therefore, we measured uptake of microcystinLR at increasing concentrations for 15 min to investigate saturability of microcystin-LR uptake with increasing concentrations. In fact, microcystin-LR uptake demonstrated saturability for both OATP1B1 (Fig. 3A) and OATP1B3 (Fig. 3B) with similar apparent $K_{\mathrm{m}}$ values of $7 \pm 3$ and $9 \pm 3 \mu \mathrm{M}$, respectively. The two transporters differed, however, in their $V_{\max }$ values. OATP1B3 transported microcystin-LR with an about 4-fold higher capacity $\left(V_{\max } 168 \pm 18\right.$ fmol/oocyte $\left.\times 15 \mathrm{~min}\right)$ as compared to OATP1B1 $\left(V_{\max } 48 \pm 8 \mathrm{fmol} /\right.$ oocyte $\times$ 15 min) (Fig. 3).

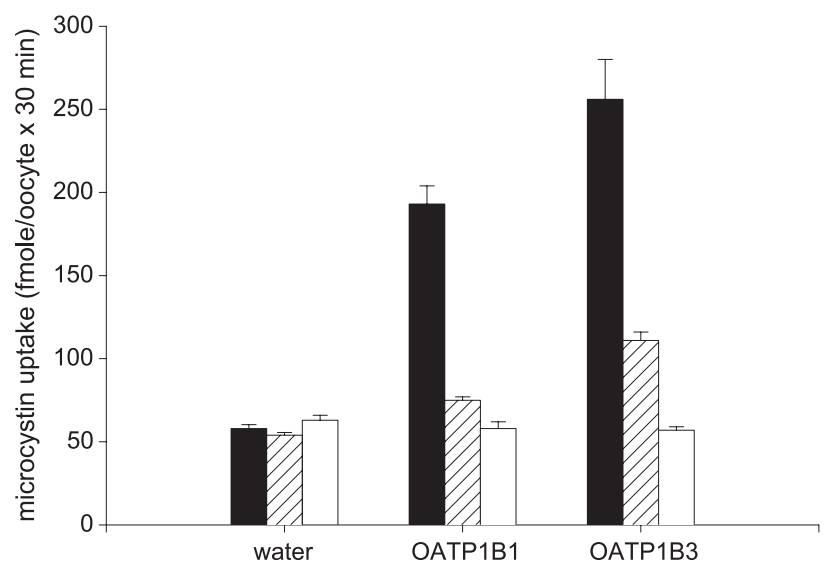

Fig. 2. Uptake of microcystin-LR into $X$. laevis oocytes expressing OATP1B1 and OATP1B3 and its inhibition by taurocholate and bromosulfophthalein. Oocytes were injected with $5 \mathrm{ng}$ of the respective cRNAs or with $50 \mathrm{nl}$ of water. After 3 days in culture, uptake of $4 \mu \mathrm{M}$ microcystin-LR was measured over $30 \mathrm{~min}$ at $25{ }^{\circ} \mathrm{C}$ in the absence (filled bars) or presence of $100 \mu \mathrm{M}$ taurocholate (hatched bars) or $50 \mu \mathrm{M}$ bromosulfophthalein (open bars). The bars represent means \pm SE of 9-10 determinations.
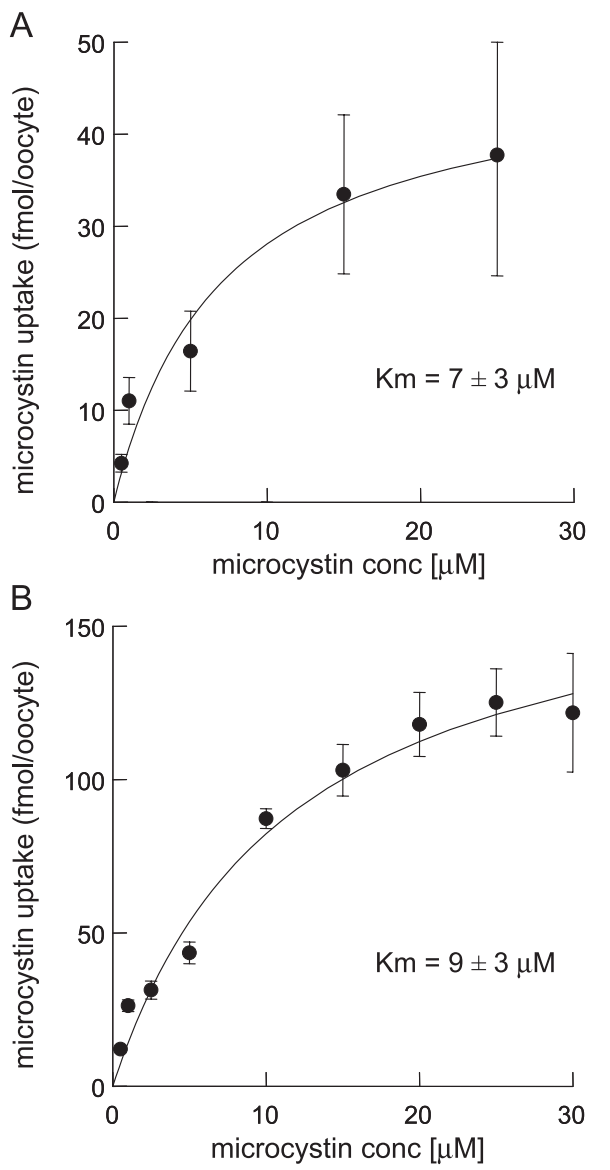

Fig. 3. Kinetics of microcystin-LR transport mediated by OATP1B1 (A) and OATP1B3 (B). Oocytes were injected with $5 \mathrm{ng}$ of the respective cRNAs or with $50 \mathrm{nl}$ of water. After 3 days in culture, initial $(15 \mathrm{~min})$ uptake of increasing concentrations of microcystin-LR was measured at $25{ }^{\circ} \mathrm{C}$. Net microcystin-LR uptake was calculated by subtracting values obtained with water-injected oocytes from the values obtained with cRNA-injected oocytes. Data from 2-3 experiments were fitted by nonlinear regression analysis to the Michaelis-Menten equation (solid line) and apparent $K_{\mathrm{m}}$ values were calculated.

\section{Transport of microcystin by brain Oatps/OATPs}

Besides Oatp1a1, Oatp1a4, and OATP2B1 that are expressed in the brain as well as in the liver, OATP1A2 is strongly expressed in brain capillary endothelial cells (Gao et al., 2000). Because Oatpla1, Oatp1a4, and OATP2B1 do not mediate transport of microcystin-LR (Fig. 1), we performed additional transport experiments with OATP1A2. As illustrated in Fig. 4 (control), OATP1A2-expressing oocytes were able to accumulate microcystin-LR approximately 4- to 5-fold above waterinjected control oocytes. Co-incubation with $100 \mu \mathrm{M}$ TC and $50 \mu \mathrm{M}$ BSP resulted in a decrease of OATP1A2mediated microcystin-LR uptake by $55 \%$ and $90 \%$, respectively. OATP1A2-mediated microcystin-LR transport was saturable with an apparent $K_{\mathrm{m}}$ of $20 \pm 8 \mu \mathrm{M}$ and a $V_{\max }$ of $91 \pm 21 \mathrm{fmol} /$ oocyte $\times 15 \mathrm{~min}$ (Fig. 5), suggesting that OATP1A2 is involved in the transport of microcystin- 


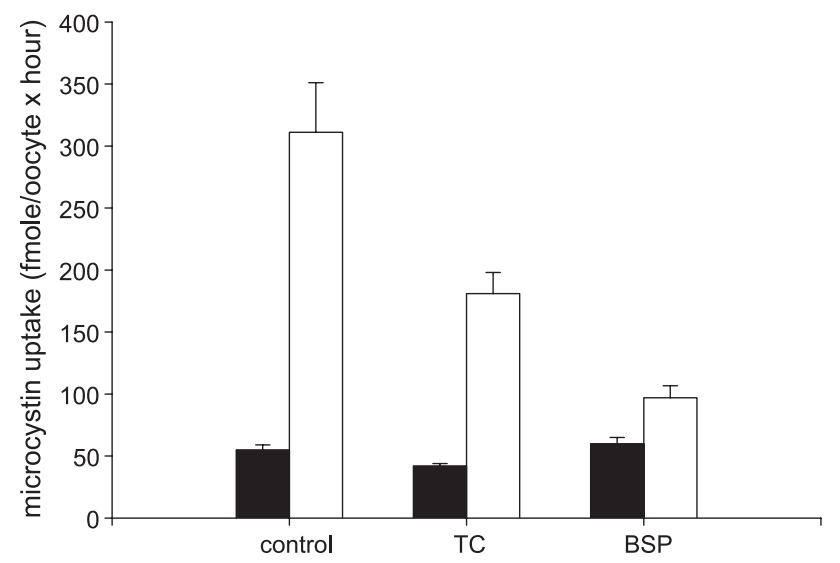

Fig. 4. Uptake of microcystin-LR into $X$. laevis oocytes expressing OATP1A2 and its inhibition by taurocholate and bromosulfophthalein. Oocytes were injected with $5 \mathrm{ng}$ of OATP1A2-cRNA (filled bars) or with $50 \mathrm{nl}$ of water (open bars). After 3 days in culture, uptake of $16 \mu \mathrm{M}$ microcystin-LR was measured over $60 \mathrm{~min}$ at $25{ }^{\circ} \mathrm{C}$ in the absence (control) or presence of $100 \mu \mathrm{M}$ taurocholate (TC) or $50 \mu \mathrm{M}$ bromosulfophthalein (BSP). The values represent means \pm SE of 12-14 uptake determinations.

LR across the blood-brain barrier (Gao et al., 2000). Unfortunately, we could not increase the microcystin-LR concentrations above $25 \mu \mathrm{M}$ because the oocytes showed clear signs of microcystin-LR toxicity (Fig. 6) and disintegrated at higher concentrations of microcystin-LR.

\section{Protection of microcystin-LR cytotoxicity in X. laevis oocytes}

When water-injected control oocytes were incubated in the presence of $15 \mu \mathrm{M}$ microcystin-LR over a time period of $15 \mathrm{~min}$, no damage of oocytes was visible (Figs. 6A and B). As a consequence of microcystin-LR uptake, OATP1A2-expressing oocytes showed a temporal increase in toxic damage over the same time period (Fig. 6C). However, co-incubation of OATP1A2-expressing oocytes with $15 \mu \mathrm{M}$ microcystin-LR and $50 \mu \mathrm{M}$ BSP largely prevented the toxicity of microcystin-LR (Fig. 6D) because of competitive inhibition of microcystin-LR uptake by BSP. Similar findings were obtained when protein phosphatase-1 and $-2 \mathrm{~A}$ activities were measured (data not shown). In OATP1A2-expressing oocytes, protein phosphatase- 1 and $-2 \mathrm{~A}$ activity was inhibited to $58 \pm 2 \%$ of that of control oocytes after $15 \mathrm{~min}$ of incubation with 15 $\mu \mathrm{M}$ microcystin-LR. In the presence of $50 \mu \mathrm{M}$ BSP, this inhibition was almost completely averted and protein phosphatase- 1 and $-2 \mathrm{~A}$ activity remained at $87 \pm 7 \%$ of control oocytes.

\section{Discussion}

The cyanobacterial toxin microcystin-LR, a cyclic heptapeptide, has been shown to exhibit hepato- and neurotoxicity in patients of a dialysis unit in Caruaru, Brazil, when the water was contaminated by blue-green algae (Pouria et al., 1998). In this study, we provide evidence that the organotropism of microcystin toxicity can be explained by microcystin transport mediated by OATPs that are expressed in the liver and at the blood-brain barrier.

Liver-specific rat Oatp1b2, human OATP1B1, and human OATP1B3 mediate uptake of microcystin-LR into hepatocytes. It has previously been shown that hepatocellular uptake of microcystins is inhibited by bile salts and BSP (Eriksson et al., 1990; Runnegar et al., 1995), suggesting that Oatps/OATPs could be involved in microcystin transport. Furthermore, several Oatps/OATPs that are expressed at the sinusoidal membrane of hepatocytes (Abe et al., 1999, 2001; Cattori et al., 2000; Hsiang et al., 1999; König et al., 2000a, 2000b) are able to transport cyclic peptides such as the endothelin antagonist BQ-123, the opioid peptide [D-penicillamin 2,5] enkephalin, and the mushroom toxin phalloidin (Meier-Abt et al., 2004). Therefore, we tested these hepatic Oatps/OATPs in the X. laevis oocyte expression system and could demonstrate that rat Oatp1b2, human OATP1B1, and human OATP1B3 indeed mediate uptake of radiolabeled microcystin-LR (Fig. 1). In addition, transport by human OATP1B1 and OATP1B3 was inhibited by co-incubation with the bile salt TC or with BSP (Fig. 2) and this OATP-mediated transport was saturable with apparent $K_{\mathrm{m}}$ values of 7 and $9 \mu \mathrm{M}$ for OATP1B1 and OATP1B2, respectively (Fig. 3). These values are very similar to the apparent $K_{\mathrm{m}}$ value reported by Eriksson et al. (1990) for freshly isolated rat hepatocytes. Thus, these results clearly demonstrate that the OATP1B subfamily members are microcystin-LR transporters. Based on their

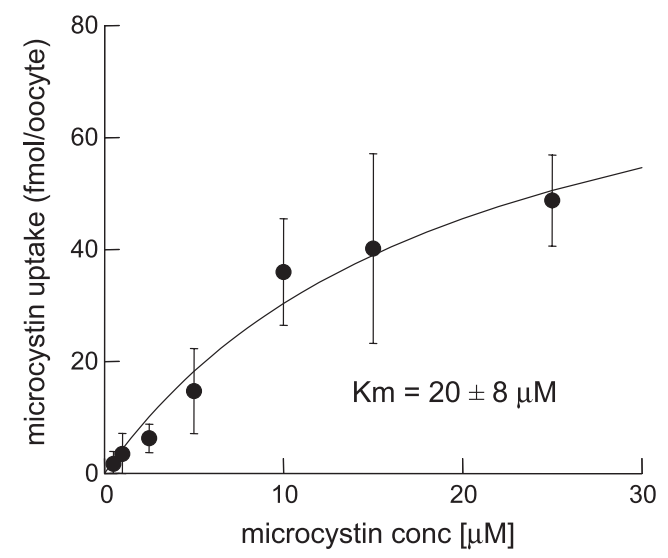

Fig. 5. Kinetics of OATP1A2-mediated microcystin-LR transport. Oocytes were injected with $5 \mathrm{ng}$ of OATP1A2-cRNA or with $50 \mathrm{nl}$ of water. After 3 days in culture, initial $(15 \mathrm{~min})$ uptake of increasing concentrations of microcystin-LR was measured at $25{ }^{\circ} \mathrm{C}$. Net microcystin-LR uptake was calculated by subtracting values obtained with water-injected oocytes from the values obtained with cRNA-injected oocytes. Data from two independent experiments ( 24 to 28 individual uptake determinations per concentration) were pooled and fitted by nonlinear regression analysis to the Michaelis-Menten equation (solid line) and apparent $K_{\mathrm{m}}$ values were calculated. 


\section{$15 \mathrm{~min}$}

$15 \mu \mathrm{M} M C$
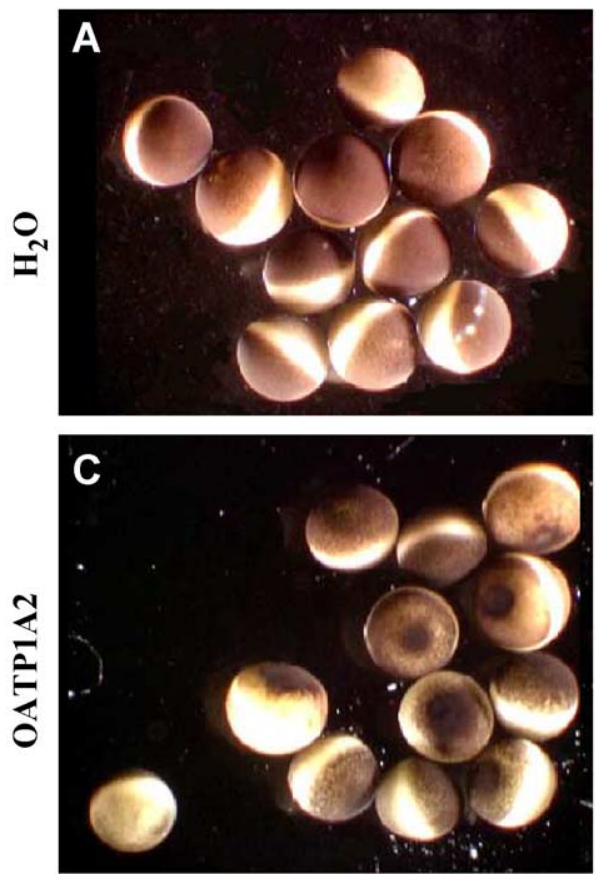

$15 \mu \mathrm{MMC}$

$50 \mu \mathrm{M}$ BSP
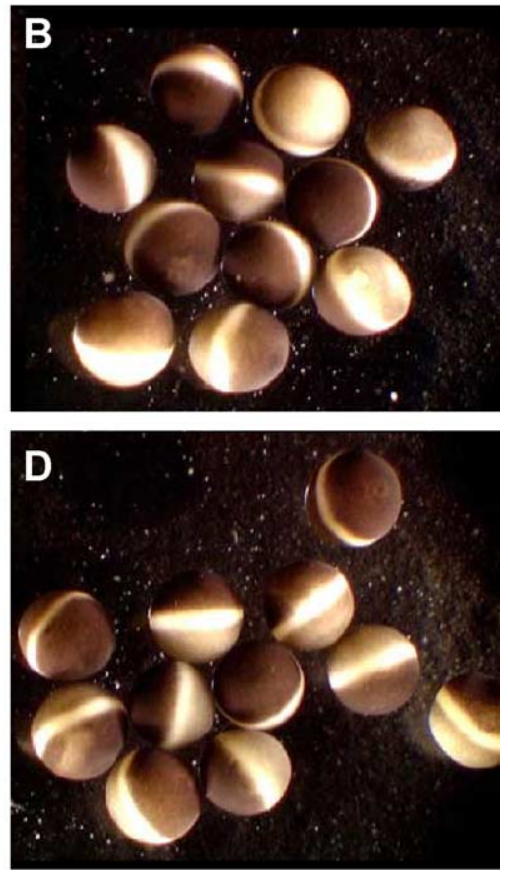

Fig. 6. Microcystin-LR-induced damage of OATP1A2-injected oocytes is prevented by bromosulfophthalein. Oocytes were injected with either $50 \mathrm{nl}$ of water or $5 \mathrm{ng}$ of OATP1A2 cRNA. After 3 days in culture, oocytes were incubated with $15 \mu \mathrm{M}$ microcystin-LR (MC) for $15 \mathrm{~min}$ or $1 \mathrm{~h}$ in the presence or absence of $50 \mu \mathrm{M}$ bromosulfophthalein (BSP) at $25{ }^{\circ} \mathrm{C}$ and pictures were taken. Healthy oocytes are characterized by a homogenous brownish coloration of the animal pole (A, B, and D). In contrast, damaged oocytes show a patchy discoloration and disintegration of the animal pole (C).

selective expression at the sinusoidal membrane of hepatocytes, they are most likely responsible for the observed hepatotoxicity of microcystin intoxications in rats, mice, and humans (Hooser et al., 1989; Jochimsen et al., 1998; Meriluoto et al., 1989; Pouria et al., 1998). However, this suggestion could only be proven directly in knockout animals that no longer express the hepatic OATP1B subfamily members. Furthermore, the identification of the cyclic heptapeptide microcystin-LR as a new substrate for Oatp1b2, OATP1B1, and OATP1B3 supports recent observations that OATP1B subfamily members are particularly good transporters for cyclic peptides (Meier-Abt et al., 2004).

Human OATP1A2, which is expressed in endothelial cells of the blood-brain barrier (Gao et al., 2000), also mediates microcystin-LR transport. Several Oatps/OATPs such as rat Oatp1a4 (Gao et al., 2000), human OATP1A2 (Gao et al., 2000), and human OATP2B1 (Gao and Meier, unpublished) are expressed at the blood-brain barrier. Among these transporters, only OATP1A2 was able to transport microcystin-LR (Figs. 1 and 4) and, similar to the liver OATPs, OATP1A2-mediated microcystin-LR transport was inhibitable by TC and BSP (Fig. 4). Furthermore, we could determine saturation kinetics with an apparent $K_{\mathrm{m}}$ value of $20 \mu \mathrm{M}$ (Fig. 5), which is only 2 - to 3 -fold above the values obtained for the OATP1B subfamily members. These results clearly demonstrate that besides the OATP1B subfamily members also OATP1A2 is able to transport microcystin-LR. Its high expression in brain (Kullak-Ublick et al., 1995) and its localization to the endothelial cells of the blood-brain barrier (Gao et al., 2000; Hagenbuch et al., 2002) suggest that human OATP1A2 could be involved in microcystin-LR transport into brain. However, we cannot exclude that additional transporters as, for example, OATP1C1 or its rodent homologues Oatp1c1, are also involved in microcystin-LR transport across the blood-brain barrier. Thus, our results suggest that OATP1A2-mediated microcystin transport across the blood-brain barrier is one of the prerequisites for the neurological symptoms of microcystin intoxication as reported by Pouria et al. (1998) and Jochimsen et al. (1998).

Microcystin-LR-induced toxicity can be prevented with known Oatp/OATP substrates. Microcystin-LR-induced damage of oocytes expressing OATP1A2 could be prevented by co-incubation with TC and BSP (Fig. 6). Similarly, we could demonstrate an alleviation of intracellular protein phosphatase- 1 and $-2 \mathrm{~A}$ inhibition by the same substrates. These observations suggest that microcystin intoxication could be reduced or even prevented in the presence of Oatp/OATP substrates. They confirm previous studies that demonstrated complete protection of lethal intoxications in mice by the known OATP1B1 and 
OATP1B3 substrate rifampin (Hermansky et al., 1991; Vavricka et al., 2002). Therefore, one can speculate that any drug with reasonable high affinity for OATP, for example, statins (Hsiang et al., 1999), could prevent lowdose microcystin intoxication, provided it is given simultaneously with or shortly after the intoxication.

In conclusion, we have identified the organic anion transporting polypeptides Oatp1b2, OATP1A2, OATP1B1, and OATP1B3 as microcystin-LR transporters in rat and man. The tissue distribution of the identified microcystinLR transporting Oatps/OATPs explains well the preferential organ toxicity of microcystins in liver and brain. Thus, Oatp1b2, OATP1B1, and OATP1B3 are responsible for uptake of microcystin-LR into rat and human hepatocytes, respectively, while OATP1A2 mediates microcystin-LR transport across the blood-brain barrier. The reduced microcystin-LR toxicity in Oatp/OATP-expressing oocytes co-incubated with BSP and TC indicates that administration of high affinity co-substrates of OATP1B1, OATP1B3, and OATP1A2 could provide a therapeutic option to reduce liver damage or neurotoxicity in microcystin-intoxicated patients.

\section{Acknowledgments}

Supported by grants 31-59204.99, 3100A0-100786/1 (to B.H.) and 31-045536.95, 31-64140.00 (to P.J.M.) from the Swiss National Science Foundation and by a grant from the European Commission DG VII INCO-Copernicus ERBIC15CT961010 (to D.R.D.).

\section{References}

Abe, T., Kakyo, M., Sakagami, H., Tokui, T., Nishio, T., Tanemoto, M., Nomura, H., Hebert, S.C., Masuno, S., Kondo, H., Yawo, H., 1998. Molecular characterization and tissue distribution of a new organic anion transporter subtype (oatp3) that transports thyroid hormones and taurocholate and comparison with oatp2. J. Biol. Chem. 273, $22395-22401$.

Abe, T., Kakyo, M., Tokui, T., Nakagomi, R., Nishio, T., Nakai, D., Nomura, H., Unno, M., Suzuki, M., Naitoh, T., Matsuno, S., Yawo, H., 1999. Identification of a novel gene family encoding human liver-specific organic anion transporter LST-1. J. Biol. Chem. 274, $17159-17163$.

Abe, T., Unno, M., Onogawa, T., Tokui, T., Kondo, T.N., Nakagomi, R., Adachi, H., Fujiwara, K., Okabe, M., Suzuki, T., Nunoki, K., Sato, E., Kakyo, M., Nishio, T., Sugita, J., Asano, N., Tanemoto, M., Seki, M., Date, F., Ono, K., Kondo, Y., Shiiba, K., Suzuki, M., Ohtani, H., Shimosegawa, T., Iinuma, Nagura, H., Ito, S., Matsuno, S., 2001. LST2, a human liver-specific organic anion transporter, determines methotrexate sensitivity in gastrointestinal cancers. Gastroenterology $120,1689-1699$.

Carmichael, W.W., 1994. Toxins of cyanobacteria. Sci. Am. 270, 78-86.

Cattori, V., Hagenbuch, B., Hagenbuch, N., Stieger, B., Ha, R., Winterhalter, K.E., Meier, P.J., 2000. Identification of organic anion transporting polypeptide 4 (Oatp4) as a major full-length isoform of the liver-specific transporter-1 (rlst-1) in rat liver. FEBS Lett. 474, $242-245$.
Chorus, I., Falconer, I.R., Salas, H.J., Bartram, J., 2000. Health risks caused by freshwater cyanobacteria in recreational waters. J. Toxicol. Environ. Health, -Part B. Crit. Rev. 3, 323-347.

Cohen, P., Alemany, S., Hemmings, B.A., Resink, T.J., Stralfors, P., Tung, H.Y.L., 1988. Protein phosphatase-1 and protein phosphatase-2A from rabbit skeletal-muscle. Methods Enzymol. 159, 390-480.

Eriksson, J.E., Paatero, G.I.L., Meriluoto, J.A.O., Codd, G.A., Kass, G.E.N., Nicotera, P., Orrenius, S., 1989. Rapid microfilament reorganization induced in isolated rat hepatocytes by microcystin-LR, a cyclic peptide toxin. Exp. Cell Res. 185, 86-100.

Eriksson, J.E., Gronberg, L., Nygard, S., Slotte, J.P., Meriluoto, J.A.O., 1990. Hepatocellular uptake of 3H-dihydromicrocystin-LR, a cyclic peptide toxin. Biochim. Biophys. Acta 1025, 60-66.

Fischer, W.J., Dietrich, D.R., 2000. Pathological and biochemical characterization of microcystin- induced hepatopancreas and kidney damage in carp (Cyprinus carpio). Toxicol. Appl. Pharmacol. 164, $73-81$.

Gao, B., Hagenbuch, B., Kullak-Ublick, G.A., Benke, D., Aguzzi, A., Meier, P.J., 2000. Organic anion-transporting polypeptides mediate transport of opioid peptides across blood-brain barrier. J. Pharmacol. Exp. Ther. 294, 73-79.

Hagenbuch, B., Meier, P.J., 2003. The superfamily of organic anion transporting polypeptides. Biochim. Biophys. Acta 1609, 1-18.

Hagenbuch, B., Meier, P.J., 2004. Organic anion transporting polypeptides of the OATP/SLC21 family: phylogenetic classification as OATP/SLCO superfamily, new nomenclature and molecular/functional properties. Pflugers Arch. 447, 653-665.

Hagenbuch, B., Scharschmidt, B.F., Meier, P.J., 1996. Effect of antisense oligonucleotides on the expression of hepatocellular bile acid and organic anion uptake systems in Xenopus laevis oocytes. Biochem. J. 316, 901-904.

Hagenbuch, B., Gao, B., Meier, P.J., 2002. Transport of xenobiotics across the blood-brain barrier. News Physiol. Sci. 17, 231-234.

Hermansky, S.J., Stohs, S.J., Eldeen, Z.M., Roche, V.F., Mereish, K.A., 1991. Evaluation of potential chemoprotectants against microcystin-LR hepatotoxicity in mice. J. Appl. Toxicol. 11, 65-73.

Hooser, S.B., Beasley, V.R., Lovell, R.A., Carmichael, W.W., Haschek, W.M., 1989. Toxicity of microcystin LR, a cyclic heptapeptide hepatotoxin from Microcystis aeruginosa, to rats and mice. Vet. Pathol. 26, 246-252.

Hsiang, B., Zhu, Y., Wang, Z., Wu, Y., Sasseville, V., Yang, W.-P., Kirchgessner, T.G., 1999. A novel human hepatic organic anion transporting polypeptide (OATP2. J. Biol. Chem. 274, 37161-37168.

Jacquemin, E., Hagenbuch, B., Stieger, B., Wolkoff, A.W., Meier, P.J., 1994. Expression cloning of a rat Liver $\mathrm{Na}^{+}$-independent organic anion transporter. Proc. Natl. Acad. Sci. U.S.A. 91, 133-137.

Jochimsen, E.M., Carmichael, W.W., An, J.S., Cardo, D.M., Cookson, S.T., Holmes, C.E.M., Antunes, M.B.D., de Melo, D.A., Lyra, T.M., Barreto, V.S.T., Azevedo, S., Jarvis, W.R., 1998. Liver failure and death after exposure to microcystins at a hemodialysis center in Brazil. N. Engl. J. Med. 338, 873-878.

König, J., Cui, Y., Nies, A.T., Keppler, D., 2000. Localization and genomic organization of a new hepatocellular organic anion transporting polypeptide. J. Biol. Chem. 275, 23161-23168.

König, J., Cui, Y., Nies, A.T., Keppler, D., 2000. A novel human organic anion transporting polypeptide localized to the basolateral hepatocyte membrane. Am. J. Physiol. 278, G156-G164.

Kullak-Ublick, G.A., Hagenbuch, B., Stieger, B., Schteingart, C.D., Hofmann, A.F., Wolkoff, A.W., Meier, P.J., 1995. Molecular and functional characterization of an organic anion transporting polypeptide cloned from human liver. Gastroenterology 109, 1274-1282.

Kullak-Ublick, G.A., Ismair, M.G., Stieger, B., Landmann, L., Huber, R., Pizzagalli, F., Fattinger, K., Meier, P.J., Hagenbuch, B., 2001. Organic anion-transporting polypeptide B (OATP-B) and its functional comparison with three other OATPs of human liver. Gastroenterology 120, 525-533.

MacKintosh, C., 1993. Assay and purification of protein (serine/threonine) 
phosphatases. In: Hardie, D.G. (Ed.), Protein Phosphorylation: A Practical Approach. Oxford Univ. Press, Oxford, pp. 197-229.

Mackintosh, C., Beattie, K.A., Klumpp, S., Cohen, P., Codd, G.A., 1990. Cyanobacterial microcystin-LR is a potent and specific inhibitor of protein phosphatase-1 and phosphatase-2A from both mammals and higher-plants. FEBS Lett. 264, 187-192.

Meier-Abt, F., Faulstich, H., Hagenbuch, B., 2004. Identification of phalloidin uptake sysems of rat and human liver. Biochim. Biophys. Acta 1664, 64-69.

Meriluoto, J.A., Sandstrom, A., Eriksson, J.E., Remaud, G., Craig, A.G., Chattopadhyaya, J., 1989. Structure and toxicity of a peptide hepatotoxin from the cyanobacterium Oscillatoria agardhii. Toxicon 27, $1021-1034$

Meriluoto, J.A.O., Nygard, S.E., Dahlem, A.M., Eriksson, J.E., 1990. Synthesis, organotropism and hepatocellular uptake of 2 tritium-labeled epimers of dihydromicrocystin-LR, a cyanobacterial peptide toxin analog. Toxicon 28, 1439-1446.

Noé, B., Hagenbuch, B., Stieger, B., Meier, P.J., 1997. Isolation of a multispecific organic anion and cardiac glycoside transporter from rat brain. Proc. Natl. Acad. Sci. U.S.A. 94, 10346-10350.

Pouria, S., de Andrade, A., Barbosa, J., Cavalcanti, R.L., Barreto, V.T.S. Ward, C.J., Preiser, W., Poon, G.K., Neild, G.H., Codd, G.A., 1998.
Fatal microcystin intoxication in haemodialysis unit in Caruaru, Brazil. Lancet 352, 21-26.

Reichel, C., Gao, B., van Montfoort, J., Cattori, V., Rahner, C., Hagenbuch, B., Stieger, B., Kamisako, T., Meier, P.J., 1999. Localization and function of the organic anion-transporting polypeptide Oatp2 in rat liver. Gastroenterology 117, 688-695.

Runnegar, M., Berndt, N., Kaplowitz, N., 1995. Microcystin uptake and inhibition of protein phosphatases: effects of chemoprotectants and selfinhibition in relation to known hepatic transporters. Toxicol. Appl. Pharmacol. 134, 264-272.

Schwimmer, M., Schwimmer, D., 1968. Medical aspects of phycology. In: Jackson, D.F. (Ed.), Algae, Man, and the Environment. Syracuse Univ. Press, Syracuse, NY, pp. 279-358

Teixeira, M.d.G., Costa, M.d.C., de Carvalho, V.L., Peirera, M.d.S., Hage, E., 1993. Gastroenteritis epidemic in the area of the Itaparica Dam, Bahia, Brazil. Bull. Pan Am. Health Organ 27, $244-253$

Vavricka, S.R., van Montfoort, J., Ha, H.R., Meier, P.J., Fattinger, K., 2002. Interactions of rifamycin $\mathrm{SV}$ and rifampicin with organic anion uptake systems of human liver. Hepatology 36, 164-172.

Watanabe, M.F., Harada, K.-I., Carmichael, W.W., Fujiki, H., 1996. Toxic Microcystis. CRC Press, Inc., Boca Raton, FL. 